\title{
Lamb Post-Mortem Protocol for Use on Farm: To Diagnose Primary Cause of Lamb Death from Birth to 3 Days of Age
}

\author{
J.M. Everett-Hincks ${ }^{*}$ and S.J. Duncan
}

AgResearch Ltd., Invermay Agricultural Centre, Private Bag 50034, Puddle Alley, Mosgiel, New Zealand

\begin{abstract}
Lamb survival is a key issue for sheep farming operations. The majority of lamb deaths from birth to weaning occur in the first 3 days after birth and range from 5\% to 30\% for individual sheep flocks. A simplified lamb post-mortem examination (PM) protocol has been developed for use on farm to determine the primary cause of lamb death between birth and 3 days of age. Firstly lamb viability at birth (LDVB) is determined and secondly the lamb death risk being dystocia (LDD), starvation and exposure (LDSE) or other (LDOTHER) is diagnosed. A trained lamb post-mortem practitioner is expected to take between 5 and 10 minutes to complete a post-mortem examination for one lamb using the protocol and decision tool described. The PM protocol is required for large scale use for AgResearch's gene marker discovery programme. Breeders involved in the Ovita Lamb Survival study are trained to use the post-mortem protocol and can access breeding values for the lamb mortality traits derived from PM: that is lamb viability at birth (LDVB), lamb death risk due to dystocia (LDD) and lamb death risk due to starvation/exposure (LDSE).
\end{abstract}

\section{INTRODUCTION}

Lamb survival is a key issue for sheep farming operations. It has been estimated that the survival to sale of an extra 100 lambs will, at last season's prices, boost income by $\$ 5000$ (pers. comm. Andy Bray, Meat \& Wool NZ, 2007). Reducing lamb losses has production, economic and animal welfare benefits.

The majority of lamb deaths from birth to weaning occur in the first 3 days after birth and range from $5 \%$ to $30 \%$ for individual sheep flocks [1]. Previous research has shown that under New Zealand conditions starvation/exposure accounts for approximately $30 \%$ of new-born lamb losses [2]. Dalton's team reported dystocia rates of $27 \%$ in dead single lambs and $17 \%$ in dead multiple lambs [3]. A recent study showed that the predominant cause of death from birth to 3 days of age was dystocia in recorded Southland ram breeding flocks, accounting for $57 \%$ of single and $47 \%$ of multiple lamb deaths [1]. Haughey suggested that $20-60 \%$ of neonatal lamb deaths categorised as starvation/exposure were actually consequences of birth stress [4]. Differing results between studies may be due to differences in clinico-pathological diagnoses.

In 2003 AgResearch's Animal Genomics Group commenced the development of a Lamb Survival Resource for a genetic marker discovery programme (funded by Ovita Ltd). An investigation into 20 ram breeder flocks involving 15,821 lambs with birth weights recorded over the 2003 and 2004 seasons, reported $4 \%$ of all lambs died as a result of difficult births (dystocia) and 1\% of all lambs died from starvation/exposure between birth and 3 days of age [5].

*Address correspondence to this author at the AgResearch Ltd., Invermay Agricultural Centre, Private Bag 50034, Puddle Alley, Mosgiel, New Zealand; E-mail: Julie.Everett-Hincks@agresearch.co.nz
The Lamb Survival Resource will continue to increase in size and scope, as a powerful nationwide resource is necessary for gene marker discovery, association and validation studies. A lamb post-mortem protocol is required for use on a large scale to increase the resource for gene marker discovery. The protocol assigns the major causes of neonatal lamb death. Farmers can use the protocol following a training session. Farmers involved in the Ovita lamb survival programme in 2007 record the major causes of lamb mortality on the national sheep recording database, Sheep Improvement Limited (SIL) [7]. Animal breeding values are available for traits derived from the post-mortem examination: that is lamb viability at birth (LDVB), lamb death risk due to dystocia (LDD) and lamb death risk due to starvation/exposure (LDSE).

The post-mortem procedure used for AgResearch's lamb survival resource was modified from McFarlane's examination method [8] in consultation with veterinary practitioners. This paper describes the post-mortem protocol that has been developed in 2007 and field tested in 43 flocks by farmers throughout New Zealand.

\section{GENERAL EXTERNAL EXAMINATION}

The basic equipment required includes a sharp butcher's knife, forceps, scales, gloves and scales to weigh the lamb and thyroids.

Lambs dead at birth and up to 3 days of age are collected, identified and recorded by the farmer during daily shepherding. The sex of the lamb is recorded. Lambs were postmortemed by trained farmers on average 12 hours after death (range 4-22 hours). Before the commencement of the postmortem examination (PM) the lamb is examined externally for physical abnormalities (e.g. cleft palate, imperforate anus, hairy shaker disease ${ }^{1}$ [9], Micropthalmia ${ }^{2}$, skeletal de-

\footnotetext{
${ }^{1}$ Lambs that are affected by Hairy Shaker Disease (HSD) have low viability and if survive, poor growth. The clinical signs of HSD are an abnormally
} 
fects, signs of predation and general status of the birth coat (e.g. groomed/cleaned, muddy).

The lamb's hooves are examined to determine whether the lamb has or has not walked. A lamb has not walked if the membranes on the hooves (white to yellowish raised areas on the soles of the feet and accessory digits) are present. If the membranes have disappeared then the lamb has walked.

\section{Lamb Birth Weight (BWT)}

The lamb is weighed to the nearest $0.1 \mathrm{~kg}$ and anatomical measurements such as crown rump length $(\mathrm{cm})$ and girth (cm) can also be recorded. The effect of birth weight on the lamb death risk traits identified by postmortem has been reported by Everett-Hincks and Dodds [5].
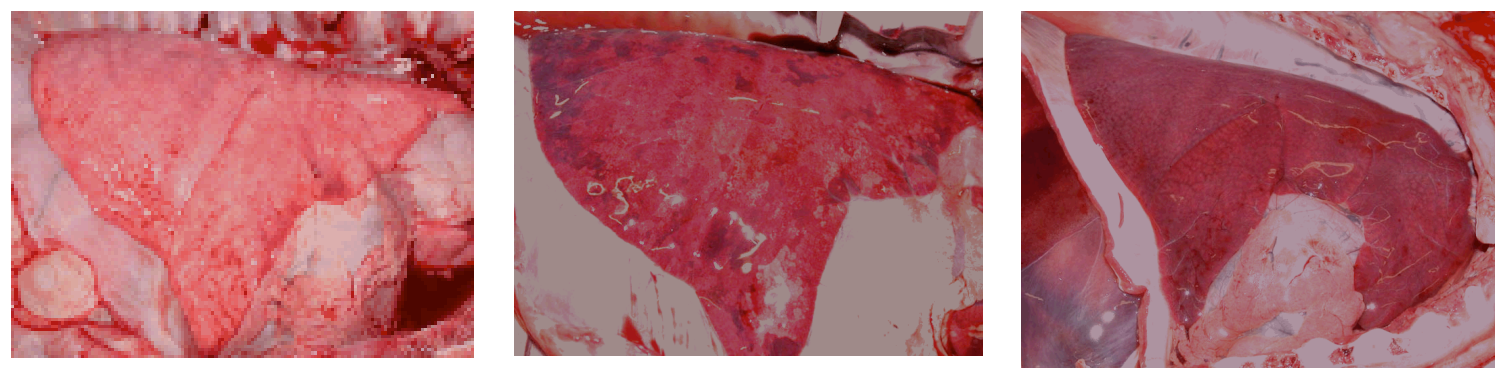

Fig. (1). Lung fully aerated, partially aerated and not aerated (from left to right). (Image courtesy of Keith Thompson, Institute of Veterinary Animal and Biomedical Sciences, Massey University, Palmerston North, New Zealand).

\section{DISSECTION AND INTERNAL EXAMINATION}

The lamb carcass is placed in a dorsal recumbent position and is dissected using a sharp butcher's knife. The dissection technique used is similar to skinning a lamb; a continuous flap is reflected from the lower lip to the pelvis removing the ventral surface of the lamb. By maintaining an upward traction of the flap down the ventral side of the neck, a horizontal cut is made through the sternum exposing the thoracic cavity keeping the knife as close to the surface of the sternum as possible not to incise the heart. The incision proceeds to the abdomen and onto the pubis removing a flap of skin, muscles and peritoneum from the abdominal cavity. It is important to keep an upward taction on the flap being reflected to ensure that the abdominal viscera are not injured. The amount of blood escaping the incised umbilical veins should be noted. The abdominal cavity requires immediate examination of signs of haemorrhage as incision of the umbilical veins or an accidental incision or puncture of the liver may lead to misdiagnosis of haemorrhage, organ rupture and subsequently a difficult birth.

Next reflect the skin from the lateral regions around the jaw, head, ventral neck, sternum, ribcage and breech. All regions and the reflected skin require immediate examination for localised subcutaneous oedema (head, neck, brisket, ribs, sternum, abdomen and breech). It is important that signs, locality and severity of localised subcutaneous oedema are noted immediately as oedema will dissipate when exposed to

coarse birth coat which may be pigmented, generally small lambs (around $1.5 \mathrm{~kg}$ ) but do not always show nervous signs (shaking).

${ }^{2}$ Microphthalmia is a well recognised inherited disease in Texel sheep. The retina is composed of an irregular mass and the animal is blind. A commercial gene marker test is available through Catapult (licensed to Ovita). the air. The prosection method has been described in detail by McFarlane [8].

\section{DIAGNOSES}

\section{Lamb Viability at Birth (LDVB)}

The thorax area is examined and the lungs are checked for aeration. If the lungs are aerated then the lamb had breathed. One of 3 classes can be assigned: full aeration, partial aeration and no aeration (Fig. 1). Partial aeration and full aeration is a sign of viability at birth. If aeration is difficult to assign then lungs should be removed and placed in a bucket of water. If a lung floats the lamb has breathed.

Organ autolysis: Lambs with signs of organ autolysis and tissue degradation have died before parturition and are pre- 

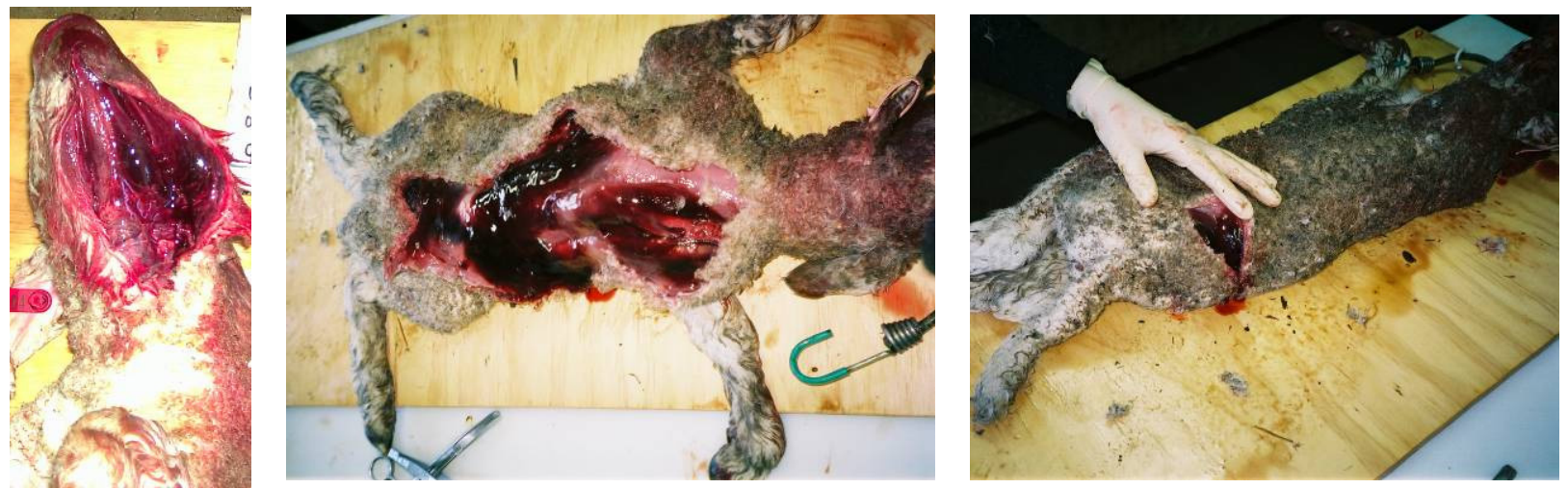

Fig. (2). Localised subcutaneous oedema on the ventral side of the jaw, severe subcutaneous oedema on body (discoloured red from freezing thawing storage process), localised subcutaneous oedema on breech (from left to right).

tion and severity can indicate different causes (Fig. 2). One of four severity grades can be assigned: no oedema, minor oedema (visible but not measurable), moderate oedema (greater than $3 \mathrm{~mm}$ and up to $1 \mathrm{~cm}$ in depth) and severe oedema (greater than $1 \mathrm{~cm}$ depth).

Oedema in distal limbs (extremities) is observed in prolonged hypothermia. Skin from the medial to lateral aspect of the hind and forelimbs is reflected for diagnosis. Oedema on the abdomen originating from the navel is a sign of infection, but uncommon in lambs that die in the first few days after birth. Generalised oedema has been suggested to be a sign of placental insufficiency, or infection in-utero and is generally classified as minor severity $(<1 \mathrm{~mm}$ thick) in all regions.
The post-mortem examination stops here if a positive diagnosis of lamb death risk to dystocia is reached. If dystocia is not assigned the post-mortem examination continues.

\section{Lamb Death Risk from Starvation/Exposure (LDSE)}

A positive diagnosis of lamb death risk from starvation/exposure is where there is evidence for all 3 of the following signs: pericardial and perirenal brown fat has been completely metabolised (Figs. 3 and $\mathbf{4}$ ), there are no milk clots in the stomach and there is no evidence of milk absorption in the gastrointestinal tract. However this is a simplified view and there are equally valid variations to this. In extreme cold weather you may observe that some lambs have metabolised all of their brown fat but have milk clots in their
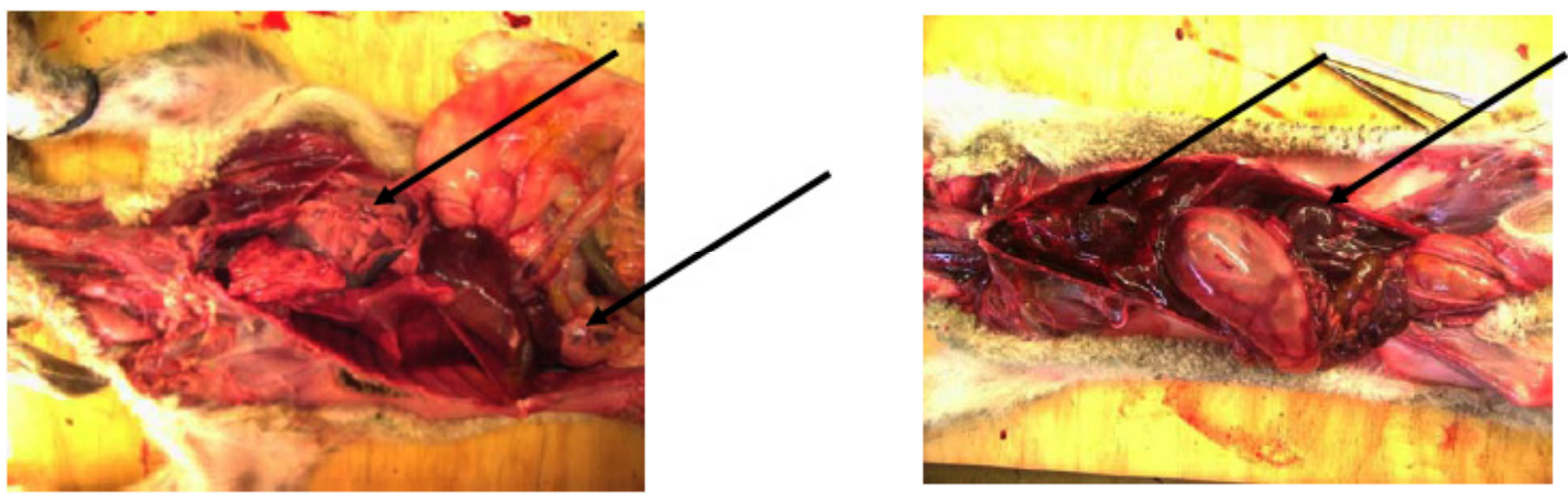

Fig. (3). Pericardial and perirenal fat: present and mobilised (from left to right).

The protocol specifies that localised subcutaneous oedema has to be greater than $3 \mathrm{~mm}$ thick (i.e. moderate severity) in at least one location before dystocia is assigned the primary cause of death (Fig. 2) [1,6].

The post mortem procedure detailed in this report prioritises dystocia as the primary cause of lamb death, as the parturition process precedes post-parturient events. Lambs that endure difficult births have trouble maintaining body temperature and have inhibited behaviours in teat searching and suckling [10]. This can increase the chances of death when subjected to cold stress or under-nutrition. Therefore lambs with dystocia and the starvation/exposure complex are assigned dystocia as the primary cause of death. stomach. These lambs have died from cold exposure and not starvation.

Firstly examine the heart and kidneys for metabolic fat depletion (Fig. 3). One of 3 classes can be assigned: full depletion, partial depletion and no depletion. If the lamb was born alive, but fails to feed, it immediately commences to metabolise the extensive body fat depots. Body fat is depleted first from the pericardium (heart) and then the perirenal (kidney) area [8]. Fat metabolism progresses from a slight softening to complete absorption where the fat tissue has become a dark reddy brown colour, is soft and gelatinous (Fig. 4). 


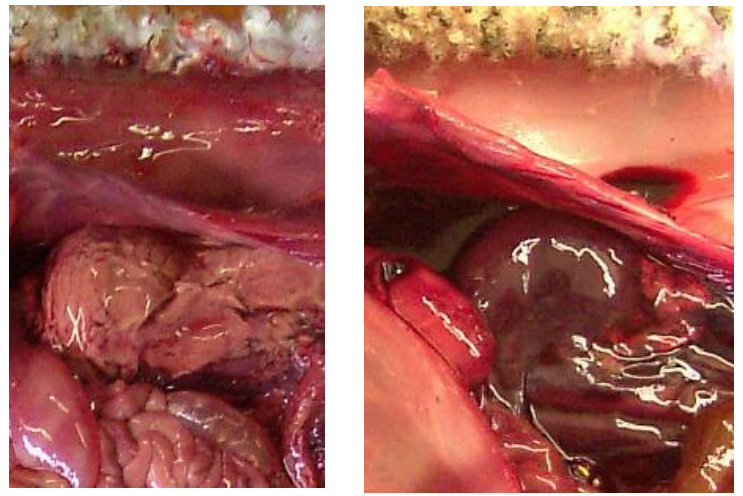

Fig. (4). Close up of perirenal fat: present and mobilised (from left to right).

Secondly the stomach is cut open and examined for milk clots. Presence of a milk clot in the abomasum is a sign that the lamb has suckled. However this is not to be confused with a lamb which has been artificially fed.

Thirdly the gastrointestinal tract is checked for milk absorption. Presence of a white scattered substance in lacteals (supporting membrane of the intestines containing the lymphatic system) indicates that the lamb has fed and digested milk. There may be no remaining milk clots in the stomach but evidence of milk absorption in the gastrointestinal tract. It is important to record if milk has passed through the whole intestinal tract. Meconium ${ }^{3}$ in the rectum is passed shortly after birth if the gastrointestinal tract is functioning normally. Meconium present in delayed and late post-parturient deaths indicates abnormal intestine function.

The post-mortem examination stops here if a positive diagnosis of lamb death risk from starvation/mismothering/ exposure (SE) is reached. If lamb death from SE is not assigned the post-mortem examination continues.

\section{Lamb Death from Other Causes (LDOTHER)}

The majority of lamb deaths between birth and 3 days of age have been assigned either LDD or LDSE [5]. There will be a smaller proportion of lambs that died from other causes. These are recorded as LDOTHER and a remark is added recording whether it was infection, abnormality or unknown.

Infection: The navel area, umbilical arteries and membranes are checked for the presence of infection. Evidence of infection may include any or all of the following: inflammation, black and/or blue tissue discolouration and oedema. The liver is checked for infection. The presence of disease foci on the liver are evidence of infection and variation in liver colour should not be confused with infection. Lamb death from infection (e.g. navel ill) is more common in older lambs.

Abnormality: Check for congenital abnormalities such as cleft palate, imperforate anus, joint problems and skeletal

\footnotetext{
${ }^{3}$ Meconium is the earliest faeces of a lamb. Unlike later faeces, meconium is composed of materials ingested during the time the lamb spends in the uterus: intestinal epithelial cells, mucus, amniotic fluid, bile and water. Meconium is sterile, unlike later faeces, is viscous and sticky like tar, and has no odour. It should be completely passed by the end of the first few days of postpartum life, with the faeces progressing toward yellow (digested milk).
}

defects. Note other abnormalities such as enlarged liver, enlarged kidneys, enlarged heart, brittle/weak ribs.

Unknown: There are always a number of dead lambs where a diagnosis for cause of death cannot be found using the post-mortem examination protocol. If symptoms do not fit any of the criteria described, record the lamb death as unknown.

\section{Iodine Deficiency}

Iodine deficiency can affect fertility and perinatal mortality, as deficient lambs have a low metabolic rate, are prone to hypothermia and have impaired suckling behaviour [11, 12]. At post-mortem examination both thyroid glands are removed and weighed in grams to determine the thyroidweight:birthweight ratios $(\mathrm{g} / \mathrm{kg})$ in newborn lambs. It has been widely accepted that a thyroid-weight:birthweight ratio $(\mathrm{g} / \mathrm{kg})$ of $>0.4$ indicate iodine deficiency $[13,14]$. It is recommended that breeding ewes are supplemented with iodine the following season to reduce iodine deficiency in their lambs. This is particularly important if ewes are fed brassica crops during pregnancy (as brassica crops are goitrogenic).

\section{SUMMARY}

An important outcome of AgResearch's lamb survival programme was the identification of simplified protocol for assessing field lamb survival and mortality measurements, which can be undertaken by ram breeders (and researchers) with minimal training. This system is scientifically backed by more detailed measurements and has resulted in accurate trait definition.

This post-mortem protocol is being used to collect data from a range of industry flocks for a gene marker discovery programme funded by Ovita Ltd. The Ovita lamb survival programme currently includes over 8000 post mortem records from 50,000 dams and 700 sires across 43 performance recorded flocks. Breeders involved in the Ovita Lamb Survival study are trained to use the post-mortem protocol and can access breeding values for the lamb mortality traits on SIL [7]. Lamb survival has an extremely high economic value within SIL (\$63) so even a small improvement in its genetic evaluation will have a significant impact on the dual purpose index. Farmers can then choose to use these selection indices to improve lamb survival rates faster than has been previously possible.

\section{ACKNOWLEDGEMENTS}

This research was funded by Ovita Ltd, Meat \& Wool New Zealand and MAF's Sustainable Farming Fund.

The authors wish to thank the many veterinary practitioners for their involvement in the project, in particular Marjorie Orr, Colin Mackintosh, John Gill and Keith Thompson. Many thanks to our wonderful farmers for their unswerving commitment and dedication to the research programme. Very special thanks to our special team. 


\section{POST MORTEM EXAMINATION AND DECISION SUPPORT TOOL \\ Step \\ \begin{tabular}{l|l}
1 & Weigh lamb $(\mathrm{kg})$ to nearest 0.1 of a $\mathrm{kg}$
\end{tabular} \\ 2 Record the lamb's gender ( $E=$ ewe lamb, $R=$ ram lamb) \\ Examine the lamb externally for physical abnormalities}

\begin{tabular}{|l|l|c|c|}
\hline 3 & Has the lamb walked? & No & Yes \\
\hline
\end{tabular}

$4 \quad$ Dissect the lamb \& expose organs

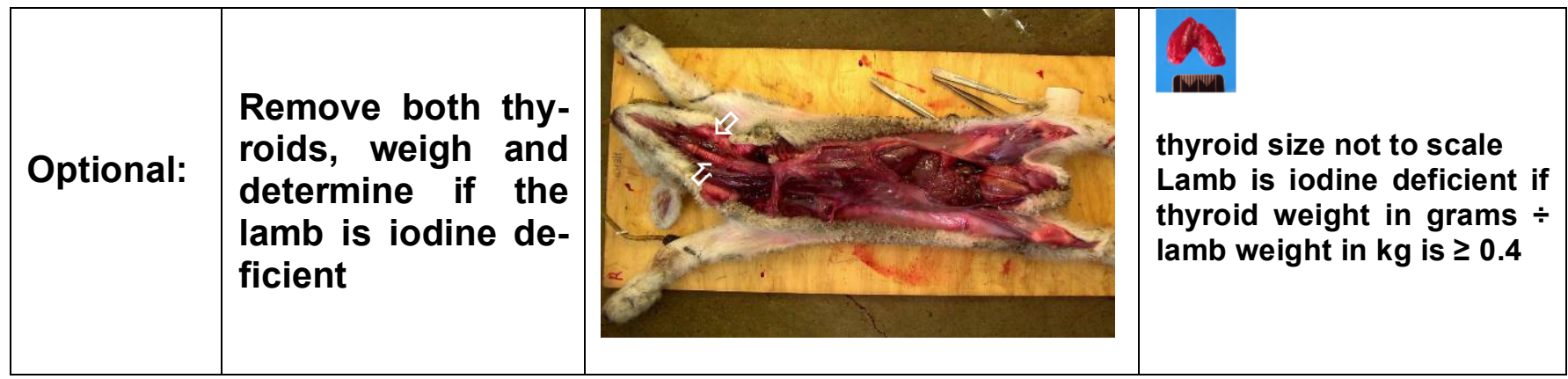

\begin{tabular}{|c|c|c|c|c|}
\hline \multicolumn{2}{|c|}{ Has the lamb breathed? } & $\begin{array}{l}\text { Picture evidence examples } \\
\text { (if Yes) }\end{array}$ & No & Yes \\
\hline 5 & $\begin{array}{l}\text { Check the lungs. } \\
\text { Are the lungs } \\
\text { aerated? (pink } \\
\text { =aerated; } \\
\text { crimson= } \\
\text { not aerated) }\end{array}$ & Fully aerated Partly aerated & $\begin{array}{l}\text { If No, go to } \\
\text { Step } 6\end{array}$ & $\begin{array}{l}\text { If Yes, go to } \\
\text { Step } 7\end{array}$ \\
\hline$\star$ & SIL Trait & $\begin{array}{l}\text { If answer 'yellow' I Yes then } \\
\text { LDVB=1 }\end{array}$ & LDVB $=0$ & LDVB $=1$ \\
\hline 6 & $\begin{array}{l}\text { Is there evidence } \\
\text { of tissue } \\
\text { degradation? }\end{array}$ & ninkich/hrow & $\begin{array}{l}\text { If No, go to } \\
\text { Step } 7\end{array}$ & $\begin{array}{l}\text { If Yes lamb died } \\
\text { before birth, go } \\
\text { to Step } 7\end{array}$ \\
\hline
\end{tabular}




\begin{tabular}{|c|c|c|c|c|}
\hline \multicolumn{2}{|c|}{$\begin{array}{l}\text { Has the lamb died from } \\
\text { Dystocia (difficult } \\
\text { birth)? }\end{array}$} & \multirow[t]{2}{*}{$\begin{array}{l}\text { Picture evidence examples } \\
\text { (if Yes) }\end{array}$} & No & \multirow[b]{2}{*}{$\begin{array}{l}\square \text { LDD=1 } \\
\text { (Dystocia) } \\
\text { Go to Step } 8\end{array}$} \\
\hline 7 & $\begin{array}{l}\text { Is there evidence } \\
\text { of a } \\
\text { haemorrhage? }\end{array}$ & & $\begin{array}{l}\text { If No, go to } \\
\text { Step } 8\end{array}$ & \\
\hline 8 & $\begin{array}{l}\text { Has the liver } \\
\text { ruptured? }\end{array}$ & & $\begin{array}{l}\text { If No, go to } \\
\text { Step } 9\end{array}$ & $\begin{array}{l}\square \text { LDD=1 } \\
\text { (Dystocia) } \\
\text { Go to Step } 9\end{array}$ \\
\hline 9 & $\begin{array}{l}\text { Is there oedema } \\
\text { under the skin? } \\
\text { (check head, } \\
\text { neck, sternum \& } \\
\text { ribcage-refer to } \\
\text { arrows) }\end{array}$ & $\begin{array}{l}\text { Localised subcutaneous oedema / 'jelly' } \\
\text { has to be greater than 3mm thick }\end{array}$ & $\begin{array}{l}\text { If No, go to } \\
\text { Step } 10\end{array}$ & $\begin{array}{l}\square \text { LDD=1 } \\
\text { (Dystocia) }\end{array}$ \\
\hline$\star$ & SIL Trait & $\begin{array}{l}\text { If one of the answers 'red' / Yes then } \\
L D D=1\end{array}$ & LDD $=0$ & LDD=1 \\
\hline \multicolumn{5}{|c|}{ If LDD=1 lamb has died from dystocia, STOP here. } \\
\hline \multicolumn{2}{|c|}{$\begin{array}{l}\text { Has the lamb died from } \\
\text { starvation/mismothering/ } \\
\text { exposure? }\end{array}$} & $\begin{array}{l}\text { Picture evidence ex } \\
\text { (if Yes) }\end{array}$ & No & Yes \\
\hline 10 & $\begin{array}{l}\text { Examine the heart } \\
\text { and kidneys. } \\
\text { Has all of the brown } \\
\text { fat been used? }\end{array}$ & & $\begin{array}{l}\text { If No, go to } \\
\text { Step } 11\end{array}$ & $\begin{array}{l}\text { If Yes, go to } \\
\text { Step } 11\end{array}$ \\
\hline 11 & $\begin{array}{l}\text { Examine the } \\
\text { stomach. } \\
\text { Is there a milk clot? }\end{array}$ & & $\begin{array}{l}\text { If No, go to } \\
\text { Step } 12\end{array}$ & $\begin{array}{l}\text { If Yes, go to } \\
\text { Step } 12\end{array}$ \\
\hline 12 & $\begin{array}{l}\text { Is there evidence of } \\
\text { milk absorption in } \\
\text { the gastrointestinal } \\
\text { tract? }\end{array}$ & & $\begin{array}{l}\text { If No, go to } \\
\text { Step } 13\end{array}$ & $\begin{array}{l}\text { If Yes, go to } \\
\text { Step } 13\end{array}$ \\
\hline$\star$ & SIL Trait & $\begin{array}{l}\text { If all answers are 'blue' then } \\
\text { LDSE }=1\end{array}$ & LDSE $=0$ & LDSE=1 \\
\hline
\end{tabular}




\begin{tabular}{|c|c|c|c|c|}
\hline \multicolumn{2}{|c|}{$\begin{array}{l}\text { Has the lamb died } \\
\text { from OTHER causes? }\end{array}$} & $\begin{array}{l}\text { Picture evidence } \\
\text { examples } \\
\text { (if Yes) }\end{array}$ & No & Yes \\
\hline 13 & $\begin{array}{l}\text { Is there } \\
\text { infection around } \\
\text { the navel? }\end{array}$ & $\begin{array}{l}x^{3} \\
-\infty\end{array}$ & $\begin{array}{l}\text { If No, go to } \\
\text { Step } 14\end{array}$ & $\begin{array}{l}\text { If Yes then } \\
\square \text { LDOTHER=1 } \\
\text { (LDremark=Infection) } \\
\text { Go to STEP } 14\end{array}$ \\
\hline 14 & $\begin{array}{l}\text { Are there } \\
\text { lesions on the } \\
\text { liver? }\end{array}$ & & $\begin{array}{l}\text { If No, go to } \\
\text { Step } 15\end{array}$ & $\begin{array}{l}\text { If Yes then } \\
\square \text { LDOTHER=1 } \\
\text { (LDremark=Infection) } \\
\text { Go to Step } 15\end{array}$ \\
\hline 15 & $\begin{array}{l}\text { Is there an } \\
\text { abnormality? }\end{array}$ & & $\begin{array}{l}\text { If No, go to } \\
\text { Step } 16\end{array}$ & $\begin{array}{l}\text { If Yes } \\
\square \text { LDOTHER=1 } \\
\text { (LDremark=abnormality) } \\
\text { Go to STEP } 16\end{array}$ \\
\hline 16 & $\begin{array}{l}\text { Is the cause of } \\
\text { death is } \\
\text { unknown? }\end{array}$ & $\begin{array}{l}\text { Don't force a diagnosis, } \\
\square \text { LDOTHER }=1\end{array}$ & if in doubt & $\begin{array}{l}\text { If Yes } \\
\square \text { LDOTHER=1 } \\
\text { (LDremark=unknown) }\end{array}$ \\
\hline$\star$ & SIL Trait & $\begin{array}{l}\text { If answers 'green' then } \\
\text { LDOTHER=1 and add } \\
\text { LDremark }\end{array}$ & LDOTHER=0 & LDOTHER=1 \\
\hline
\end{tabular}

If LDOTHER=1 lamb has died from Other causes. Add Remark.

\section{Check that you have completed the $\star$ ( $\star$ refer to the SIL traits)}

\section{REFERENCES}

[1] Kerslake JI, Everett-Hincks JM, Campbell AW. Lamb survival: a new examination of an old problem. In: Proceedings of the New Zealand Society of Animal Production 2005; 65: pp. 13-18.

[2] McCutcheon SN, Holmes CW, McDonald MF. The starvationexposure syndrome and neonatal lamb mortality: A review. In: Proceedings of the New Zealand Society of Animal Production 1981; 41: pp. 209-217.

[3] Dalton DC, Knight TW, Johnson DL. Lamb survival of sheep breeds on New Zealand hill country. NZ J Agric Res 1980; 23: 167-173.
Haughey KG. Selective breeding for rearing ability as an aid to improving lamb survival. Australian Vet J 1983; 60(12): 361-363.

Everett-Hincks JM, Dodds KG. Management of maternal-offspring behaviour to improve lamb survival in easy care sheep systems. J Anim Sci 2008; 86: E259-E270.

[6] Everett-Hincks JM, Dodds KG, Kerslake JI. Parturition duration and birthing difficulty in twin and triplet lambs. In: Proceedings of the New Zealand Society of Animal Production 2007; 67: 55-60.

[7] Newman S-AN. Making better use of the SIL genetic engine. In: Proceedings of the New Zealand Society of Animal Production 2003; 63: 194-196.

[8] McFarlane D. Perinatal lamb losses. 1. An autopsy method for the investigation of perinatal losses. NZ Vet J 1965; 13: 116-135. 
[9] Manktelow BW, Porter WL, Lewis KHC. Hairy shaker disease of lambs. NZ Vet J 1969; 17: 245-248.

[10] Eales FA, Gilmour JS, Barlow RM, Small J. Causes of hypothermia in 89 lambs. Vet Rec 1982; 110: 118-120.

[11] Caple IW, Nugent GF. Relationships between plasma thyroxine concentrations and the responses of newborn lambs to hypothermia. In: Proceedings of the Australian Society of Animal Production 1982; 14: 657.
[12] Potter BJ, Man MT, Belling GB, et al. Retarded fetal brain development resulting from severe dietary iodine deficiency in sheep. Neuropathology and Applied Neurobiology 1982; 8: 303-313.

[13] Mulvaney C. The role of iodine in Merino sheep. Is there a subclinical condition affecting lamb survival? In: Proceedings of the Sheep and Beef Cattle Society of the New Zealand Veterinary Association 1997; 27: 117-124

[14] Sargison ND, West DM, Clark RG. The effects of iodine deficiency on ewe fertility and perinatal lamb mortality. NZ Vet J $1998 ; 72-75$

(C) Everett-Hincks and Duncan; Licensee Bentham Open.

This is an open access article distributed under the terms of the Creative Commons Attribution License (http://creativecommons.org/license/by/2.5/), which permits unrestrictive use, distribution, and reproduction in any medium, provided the original work is properly cited. 